\title{
The Significance of the Divine Torah in Ptolemaic Egypt in Documentary and Literary Sources from the Third and Second Centuries BCE
}

\author{
Altmann, Peter
}

\begin{abstract}
This essay analyzes the Torah's role in Judean communities from Ptolemaic Egypt in order to evaluate the significance of the Judean claim of divine origins for their law in relation to the conceptual or functional nature of this law. An introductory step explores the nature of the Judean communities in Egypt under the Ptolemies. The essay then moves to consider the nature of judicial practice in Ptolemaic Egypt, especially among Judean communities, where scholars have asserted overlap with the written Greek Torah in the interpretation of legal records. Given the largely negative finds from papyri documents concerning practical judicial conceptions, the discussion turns to depictions of Torah in the Letter of Aristeas and other Hellenistic-Judean literature. The argument demonstrates that direct references to the Torah conceive of its importance in philosophical terms and group affiliation rather than judicial categories, even when the conception of God as a divine legislator emerges.
\end{abstract}

DOI: https://doi.org/10.1163/15700631-bja10036

Posted at the Zurich Open Repository and Archive, University of Zurich

ZORA URL: https://doi.org/10.5167/uzh-205274

Journal Article

Published Version

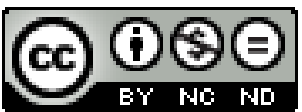

The following work is licensed under a Creative Commons: Attribution-NonCommercial-NoDerivatives 4.0 International (CC BY-NC-ND 4.0) License.

Originally published at:

Altmann, Peter (2021). The Significance of the Divine Torah in Ptolemaic Egypt in Documentary and Literary Sources from the Third and Second Centuries BCE. Journal for the Study of Judaism, 52:1-31. DOI: https://doi.org/10.1163/15700631-bja10036 


\title{
The Significance of the Divine Torah in Ptolemaic Egypt in Documentary and Literary Sources from the Third and Second Centuries BCE
}

\author{
Peter Altmann | ORCID: 0000-0003-4622-7721 \\ University of Zurich, Zurich, Switzerland \\ peter.altmann@uzh.ch
}

\begin{abstract}
This essay analyzes the Torah's role in Judean communities from Ptolemaic Egypt in order to evaluate the significance of the Judean claim of divine origins for their law in relation to the conceptual or functional nature of this law. An introductory step explores the nature of the Judean communities in Egypt under the Ptolemies. The essay then moves to consider the nature of judicial practice in Ptolemaic Egypt, especially among Judean communities, where scholars have asserted overlap with the written Greek Torah in the interpretation of legal records. Given the largely negative finds from papyri documents concerning practical judicial conceptions, the discussion turns to depictions of Torah in the Letter of Aristeas and other Hellenistic-Judean literature. The argument demonstrates that direct references to the Torah conceive of its importance in philosophical terms and group affiliation rather than judicial categories, even when the conception of God as a divine legislator emerges.
\end{abstract}

\section{Keywords}

Divine Law - Septuagint - Pentateuch - Ptolemaic Egypt - Letter of Aristeas 


\section{Introduction ${ }^{1}$}

In Let. Aris. 31, Demetrius, royal librarian of Alexandria, writes to the king regarding the Torah: "these books, having been made exact, be with you, because this legislation is very philosophical and uncorrupted, inasmuch as it is divine." ${ }^{2}$ Despite questions concerning its historical veracity, this text

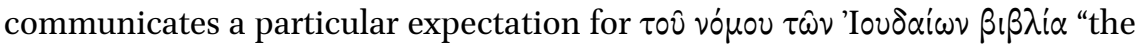
books of the law of the Judeans" (Let. Aris. 30) on the basis of its divine nature. Specifically, the books are expected to receive approval in terms of Greek

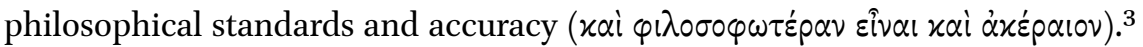
Thus, at some point in the Ptolemaic period, wherever one might place the Letter of Aristeas, ${ }^{4}$ one group, likely from the Alexandrian Judean community, posited that one could expect the divine status of the biblical "law books" to be equated with their philosophical and genuine nature.

This divine attribution for the Torah in the Letter of Aristeas provides a platform to inquire about the wider significance and function of the Greek Pentateuch in the context of Ptolemaic Egypt, especially among Judeans ${ }^{5}$ given the presumable Judean authorship of the Letter of Aristeas. For example, in itself, this statement in Let. Aris. 31 does not make direct declarations about the conception of the Judean Torah as legally binding. However, perhaps such connotations are implicit, or can law be shown to adhere to a different type of conception?

Expanding the question of the significance of the Torah in this way invariably leads to the broad and unfinished debate on its path to authoritative

1 This project has received funding from the European Research Council (ERC) under the European Union's Horizon 2020 research and innovation program grant agreement No. 833222. My thanks to the members of the University of Zurich "Divine Law" SeminarDylan Johnson, Phillip Lasater, Lida Panov, Konrad Schmid, and especially Anna Angelini, as well as Sylvie Honigman for their helpful feedback on earlier drafts of this essay. All shortcomings naturally remain my own.

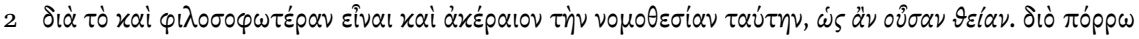

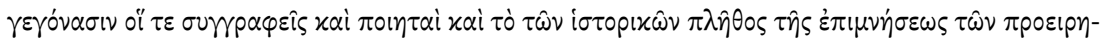
$\mu \varepsilon \dot{v} \omega \nu \nu$ ८ $\beta \lambda i \omega \nu$. Unless otherwise noted, translations follow Wright, Letter of Aristeas. Italics added. For a similar conception, see also Let. Aris. 3 for mention of the "divine law."

3 A similar remark on the treatment of the Torah as philosophy appears in Collins, "Law," 375.

4 Many scholars date the letter around the middle of the second century вСЕ, though recently argued to be at least fifty years later by Lange, "Textual Standardization," 62. However, the dependence of the Letter of Aristeas on the Greek introduction to Sirach, the key plank of his argument, remains questionable. See Wright, Letter of Aristeas, 6 o.

5 I am using the term "Judean" broadly to include those who identify with practices related to YHWH worship or Hebrew language following Mason, "Jews, Judaeans." The debate on the correct terms - "Judean" and/or "Jew" —is quite extensive. See also, e.g., Collins, Invention of Judaism, 1-19; Cohen, Beginnings of Jewishness. 
status - and the meaning of this status - in early Judaism. Recent discussion on the importance of the Torah as law oscillates between placing the decisive development of the authority of pentateuchal law in the Persian and the Hellenistic periods. Placement in the Persian period often relies on some notion of "Persian authorization" associated, though often in modified form, with the thesis proposed by Peter Frei. ${ }^{6}$ Some scholars instead argue for a decisive development internal to Judean communities during this time. ${ }^{7}$ However, especially Reinhard Kratz points to the paltry extra-biblical evidence from Elephantine, Mesopotamia, and Samaria for the practical judicial importance of the Torah for Yahwistic communities during this period. ${ }^{8}$

Michael LeFebvre instead argues that the Torah became a basis for legal decisions in Egypt in the Ptolemaic period. ${ }^{9}$ He largely follows the conclusions of Joseph Mélèze Modrzejewski, who proposes that this step took place as a result of the presence of an imperial Ptolemaic judicial system that allowed Judean courts to adjudicate disputes on the basis of a Judean law. In his view, the written Greek Torah became this legal foundation. ${ }^{10}$ Finally, Jonathan Vroom proposes a more differentiated conception of "authoritative," placing the decisive movement to practical (binding) legal authority in the people of the legal experts in Persian Yehud, but more concretely as the writing of the Law itself on display in Hellenistic-period Palestinian documents such as the Temple Scroll and Samaritan Pentateuch. ${ }^{11}$

The following essay analyzes one aspect important for this discussion: the position of the Torah in Judean communities located in Ptolemaic Egypt. However, it does so with the particular purpose of evaluating the significance of the Judean claim of divine origins for their law with regard to the conceptual or functional nature of this law. My discussion proceeds as follows: (1) An introductory step explores the nature of the Judean communities in Egypt under the Ptolemies. It then moves (2) to consider the nature of judicial practice in Egypt, especially for Judean communities, under the Ptolemies where assertions of overlap with pentateuchal traditions are made in the interpretation of legal records. Given the largely negative finds from papyri documents

$6 \quad$ Frei and Koch, Reichsidee; Frei, "Persian Authorization." See further discussion in the other essays from the same volume (Watts, Persia and Torah); and in Knoppers and Levinson, Pentateuch as Torah. More recent affirmations of the Torah's authoritative status in the Persian period appear in Collins, 53-60; Lee, Authority and Authorization.

7 See Ska, “Persian Authorization," esp. 178.

8 Kratz, "Fossile Überreste"; Kratz, Historical Israel, 140-53, $175-87$.

9 LeFebvre, Collections, Codes, Torah.

10 Mélèze Modrzejewski, Jews of Egypt, 106-15, esp. 110-11; LeFebvre, 146-73.

11 For a summary of his position see Vroom, Authority of Law, 211-12. His study unfortunately does not consider the Letter of Aristeas or papyri from Ptolemaic Egypt. 
concerning practical judicial conceptions, (3) the discussion turns to alternative depictions of Torah in the Letter of Aristeas and other Hellenistic-Judean literature. A summary (4) concludes the essay.

\section{Judean Presence in Egypt}

The evidence on the Persian-period Judean Elephantine military community that primarily but not exclusively worshiped YHWH in Upper Egypt goes silent around 400. ${ }^{12}$ This and related Judean communities in Egypt provide some evidence of their familiarity with traditions that appear in the Bible texts, specifically the spring celebration of Passover/Unleavened Bread found in the so-called Passover Papyrus (TAD A4.1), an instructional letter (TAD D7.6 l. 9), and in a broken context (TAD D7.24 l. 5).13 These documents show the importance of Yahwistic cultic traditions in these communities that agree in some aspects with Torah regulations, yet they do not extend to legal matters in family, economic, or other spheres of life in Persian-period Egyptian Judean (or YHWH-worshipping) communities.

Various claims support an increase in Judean presence in Egypt early in the Hellenistic period. Josephus states that Judeans participated in the founding of Alexandria, receiving a district for themselves. ${ }^{14}$ Though this specific claim remains dubious, ${ }^{15}$ Let. Aris. ${ }^{12-27}$ declares that Ptolemy I took numerous captured slaves from Palestine to Egypt (likely in 312 or $302 \mathrm{BCE}$ ). Josephus also records a different tradition, received from (Pseudo-) Hecataeus, that many Judeans instead chose to move there on their own. ${ }^{16}$ In any case, in addition to established Judean communities such as at Edfu that endured from the Persian period, ${ }^{17}$ new ones sprung up early under Lagid (Ptolemaic) hegemony. Over the course of Ptolemaic rule, documents attest both to Judean communities in Alexandria and colonies in the Fayum settled in early waves of migration as well

12 Porten, Archives from Elephantine, 301. I am unconvinced by van der Toorn's speculative argument that this community was originally Samari(t)an, though he does highlight the likely presence of Samaritan communities in Egypt: see his Becoming Diaspora Jews.

13 For extended discussion see Granerød, Dimensions of Yahwism.

14 Josephus, Ag. Ap. 2.4; cf.J.W. 2.487-488; Ant. 19.281; 12.8.

15 Gruen, Diaspora, 71; Honigman, “'Politeumata' and Ethnicity," 82.

16 Josephus, Ag. Ap. 1.186.

17 Evidence that Jews had resided in Edfu since the Persian period appears in the similarities in the structure of their community to that of Elephantine. There are also economic records containing Hebrew, Yahwistic, or Judean names in TAD C3.28. For details see Honigman, “Jewish Communities," 122; Mélèze Modrzejewski, Jews of Egypt, 74-76. 
as to later settlements such as Leontopolis and Herakleopolis. ${ }^{18}$ Furthermore, given some trade in slaves from the southern Levant sold to Egyptian masters documented in the Zenon Papyri, ${ }^{19}$ Judeans were to be found even more widely dispersed than solely in the abovementioned "Judean" communities.

Arguments have been made in favor of the high status of a number of Judeans within the Ptolemaic administration based on later literary texts. The most celebrated example concerns one Dositheos appearing in the later book of 3 Maccabees as a Judean, whom Mélèze Modrzejewski among many others equates with Dositheos, son of Drimylos from third-century BCE papyri as a high "memorandum writer" who went on to serve as the priest of the royal Ptolemaic cult, a position so exalted that it was once held by the brother of the king himself. ${ }^{20}$ Some evidence is also found for significant Judean members of the Ptolemaic military establishment. ${ }^{21}$

With regard to the focus of this essay, a core question concerns the degree to which these individuals and communities shared a common "Judean" identity and, more specifically, the same view of the "Torah." Given the wide temporal spectrum for the relocation of Judeans/YHWH-worshippers to Egypt as well as the diverse geographic nature of their communities and residences, I presume that different Judeans might offer varying conceptions for the distinguishing marks that identified them as "Judean." Each group might have responded to the diverse challenges confronting their particular community by defining their ethnic identity in a variety of ways. ${ }^{22}$ Still, a few repeated practices transgress the limits of the separate Judean communities: use of several of the names of the patriarchs, names related to Sabbath (Sabbataios), and names

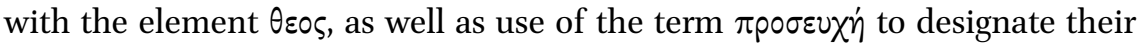
cultic places. ${ }^{23}$ Thus, the common practices that span names and worship largely remain within the familial and cultic spheres.

One important piece of the puzzle with regard to Judean communities in this period is that they were a subset of "Greeks" when viewed in terms of the Greek-Egyptian dichotomy of the Ptolemaic administration..$^{24}$ In other words,

18 For an overview see Mélèze Modrzejewski, 73-98; Honigman, "Jewish Communities."

19 Pertinent documents include $C P J$ 1.1, 4, 7.

$20 \quad C P J 1.127 \mathrm{a}, \mathrm{d}-\mathrm{e}$.

21 E.g., the fanciful story from (Pseudo-)Hecataeus recorded by Josephus, Ag. Ap. 1.201-204, of a Judean archer killing a bird that an augur was observing to derive a divine sign for the army; Ant. 13.285 on the Judean generals Onias and Helkias. See also CPJ 1, 18, 23, 24, 27, along with Let. Aris. 13,36 .

22 Honigman, "Jewish Communities," 119-20.

23 See Honigman, "Ptolemaic Definitions," 41-46. As I will indicate below, I am less confident of her contention of a separate family law.

24 Honigman, $48-52$, provides and explains the helpful terminology of "nested identity." 
they belonged to the category of foreigners superior to "native Egyptians." Thus, one finds individuals designated as Ioudaioi in some contexts, and in others as "Greeks." The latter served as a nested ethnic identity that indicated tax status: Those associated with royal service—such as Judean members of the military_-paid some taxes at lower rates. ${ }^{25}$

Second, Judeans in Ptolemaic Egypt, at least in some locales at some points in time, conducted some of their own political affairs. As Honigman notes, the Aramaic letter TAD D1.17 l. 1 (dated to the third century) ${ }^{26}$ mentions "judges" $\left(d_{n n y}\right)$ in Edfu, which may be a legacy from the Persian administrative structures. No detailed information is extant for the basis on which these judges in an Upper Egyptian context might make their decisions, which is unsurprising given the limited context.

In a later development, the second-century Greek papyri from Herakleopolis clearly attest to a Judean politeuma (judicial administration) that carried out administrative tasks and received appeals to arbitrate judicial conflicts. ${ }^{27}$ However, it remains unclear at what point such Judean politeumata came into existence, whether in Herakleopolis, Alexandria, Leontopolis, or elsewhere. ${ }^{28}$ Papyri from Herakleopolis show its Judean politeuma in operation in the mid-second century BCE, which also coincides with the proposed date for the Letter of Aristeas and the appearance of the term in connection with the Alexandrian Judean community at that time. However, it remains unsubstantiated and problematic to retroject these mid-second-century institutions onto earlier Egyptian Judean communities. ${ }^{29}$

Nonetheless, the early evidence for the translation of the Septuagint in Egypt, found in both Egypt and in Palestine, indicates a certain level of literary competency and regard for the Torah among Jews in Egypt by the mid-third century вСЕ. ${ }^{30}$ Additional support for literary proficiency in Greek among Judeans in Egypt also comes in the form of the third-century Zenon papyri and Hellenistic-Judean compositions, such as those by Ezekiel the Tragedian in the early second century and Artapanus from the end of the third. ${ }^{31}$ Especially

25 Honigman, "Jewish Communities," 81-82. She notes evidence from the mid-third century BCE. Similar evidence is cited by Aitken, "Language," 133 arguing that such scribes represent the circle from which the Septuagint first emerged.

26 See http://cal.huc.edu/get_file_info.php? coord=22554117.

27 Cowey and Maresch, Urkunden des Politeuma, 10-17; Sänger, "Jurisdiktion," 215-32; Honigman, "Politeumata' and Ethnicity," 63.

28 There are good reasons to accept a second-century date for their establishment in Egypt: see Honigman, "Ptolemaic Definitions," 42-43, 53-56.

29 For discussion see Honigman, "Politeumata' and Ethnicity," 67-76.

$30 \quad$ See Kreuzer, "Origins and Transmission," 13.

31 Following the dates given by Robertson, "Ezekiel the Tragedian" and Collins, Athens and Jerusalem, 39, 225. 
the presence of the Septuagint raises the question of the importance and conception of the Pentateuch for Egyptian-Judean communities in this period. Did it serve them as positive law, that is, law backed by the authority of the state functioning as the basis for legal decisions?

\section{Law and Judean nomos in Ptolemaic Egypt}

As others have discussed in significant detail, the judicial system in Ptolemaic Egypt consisted of various institutions and processes. ${ }^{32}$ The king naturally served as the ultimate source of law, and his $\delta 1 \alpha \gamma p \alpha \mu \mu \alpha \tau \alpha$ (regulations) and $\pi p o \sigma \tau \dot{\alpha} \gamma \mu \alpha \tau \alpha$ (ordinances) constituted the highest level of authoritative law, both in terms of administrative execution and adjudication of disputes. ${ }^{33} \mathrm{In}$ terms of confluence with longstanding Egyptian practice, the Ptolemaic rulers continued the pharaonic tradition of portraying the ruler as the embodiment of Ma'at. And, on a very concrete level, acquaintance with the royal edicts extended all the way to local disputes between Egyptians, where they could be cited. ${ }^{34}$

However, as was true both in earlier Persian and also in broader Greek patterns of imperial administration, the Ptolemaic rulers affirmed or validated traditions in the lands they conquered..$^{35}$ The accepted understanding put forward by the seminal study by H.-J. Wolff is that, in addition to the direct, ad hoc, edicts put forward by the kings, a two-tiered judicial system took root, on one hand for the "Egyptians" ( $\lambda \alpha$ xppi $\left.^{\prime} \alpha \mathrm{l}\right)$ and on the other for the "Greeks" $\left(\delta\left(x \alpha \sigma \tau \tau^{\prime} \rho(\alpha) \cdot{ }^{36}\right.\right.$ Each group typically went to their specific judicial authorities in the case of disputes, and decisions were carried out on the basis of the separate traditions-likely consisting predominantly of customary law. ${ }^{37}$

\footnotetext{
32 See, with bibliography, Manning, Last Pharaohs, 165-200.

33 Manning, 170.

34 Manning, 167-68. An example appears in pTebt. III/1 780, from Tebtynis (Arsinoites/ Fayum), which dates to 171 BCE. Lines 12-14 read, "But the ordinance declares 'If any person build upon the land of another, let him be deprived of the building"': see http:// papyri.info/ddbdp/p.tebt;3.1;78o?rows=3\&start=81\&fl=id,title\&fq=series_led_path:P.Tebt ;3; ; ; \&sort=series+asc,volume+asc,item+asc $\& p=82 \& \mathrm{t}=387$

35 The Hellenistic example of the affirmation of the ancestral laws of the conquered Nisyroseans by Philip V in 201 вCE is noted by Collins, Invention of Judaism, 10-11. For discussion of Persian examples see the literature above in n. 6.

36 Wolff and Rupprecht, Recht, 2:71-97. For a recent summary, see Lippert, "Egyptian Law."

37 Manning, Last Pharaohs, 177-78.
} 
2.1 Judeans in "Greek" Courts

Within this broad overview, the first documents concerning Judeans and legal action on the basis of some kind of Judean tradition appear in the third century всЕ in courts designated for Greeks - which included Judeans. ${ }^{38}$ On the basis of these documents and later ones emerging from specifically Judean administrative polities, a broad collection of scholars, generally following the work of Mélèze Modrzejewski, understands the foundation for the legal decisions and appeals in these documents to consist of the Greek Torah. Sänger goes so far as to conclude

Über eines scheint aber Einigkeit zu herrschen: Der jüdische nomos, die jüdische Religion, niedergelegt in der Torah bzw. ihrer griechischen Version, der Septuaginta, war von der ptolemäischen Regierung öffentlich als Rechtsquelle anerkannt worden. ${ }^{39}$

However, as my discussion will indicate, the basis for this declaration remains too slim to support the conclusion.

As a prelude to discussing the papyri, it is noteworthy that Mélèze Modrzejewski proposes that the very reason for the translation of the Pentateuch into Greek was the Ptolemaic ruler's desire to use it as the basis for judicial action among Judeans in Egypt, parallel to the Demotic Case Book found in Oxyrhynchus. ${ }^{40}$ While there $i$ s evidence for the translation of Egyptian law into Aramaic even under Darius around $500 \mathrm{BCE},{ }^{41}$ and thus perhaps also into Greek at a later point, I suggest that this does not serve as the best analogy for understanding the translation of the Pentateuch. The

$38 \quad C P J 1.19$

39 Sänger, "Jurisdiktion," 220. Italics added. Earlier (p. 219) he states, "Zum anderen gibt es guten Grund zu der Annahme, daß die Torah, das Gesetzesbuch des hellenistischen Judentums_-die fünf Bücher Mose, griechisch Pentateuch-Teil der von der ptolemäischen Regierung anerkannten politikoi nomoi, also der 'bürgerlichen Gesetze', war. Diese Verknüpfung geht ebenfalls auf Wolff zurück und wurde von Mélèze Modrzejewski anerkannt; und auch Cowey und Maresch haben auf diese ganz wesentliche Beobachtung hingewiesen." Note his monograph ptolemäische Organisationsform, 128-29, which repeats these statements verbatim. See also Manning, Last Pharaohs, 182. Rather skeptical, on the other hand, is Collins, "Law," 377-78.

40 Mélèze Modrzejewski also takes the Letter of Aristeas at face value with regard to its assertion of an early time of translation and argues that both it and the Demotic Case Book were inserted into the Ptolemaic judicial system:Jews of Egypt, 110. He is somewhat more reticent in "Septuagint as Nomos," in 186-87. See the problems with his theory raised by, e.g., Aitken, "Language."

See Lippert, "codification." 
striking distinctions between the two texts as well as the questionable suitability of the Pentateuch as a practical basis for judicial actions undermine Mélèze Modrzejewski's proposal. ${ }^{42}$ However, one could rightly reject his hypothesis on the motivation for translation of the Pentateuch and still contend that the Septuagint later became the basis for legal practice among Egyptian Judeans, ${ }^{43}$ though the issue of the suitability of the Pentateuch still remains. In any case, discussion of the individual texts shows the problems with the supposition that the Pentateuch functioned as the basis of legal judgments for Judeans in Ptolemaic Egypt in all extant legal papyri.

One important text in this discussion is the fragmentary papyrus of $C P J 128$, dated to $218 \mathrm{BCE}$, which concerns some kind of marital dispute. It is addressed to King Ptolemy, not a Judean leader. ${ }^{44}$ The key lines (r.1-9) are as follows: ${ }^{45}$

\begin{tabular}{|c|c|}
\hline 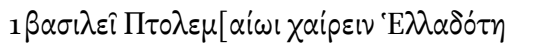 & To King Ptolem[y. Greetings from \\
\hline 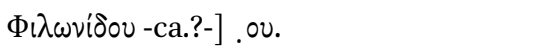 & Helladote, daughter of Philonides. I ...] \\
\hline$\sigma \cup \nu \gamma p \alpha \psi \alpha[\mu \varepsilon \dot{v} \circ v]$ & He [has] agreed \\
\hline 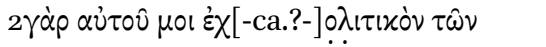 & For me, his $[\ldots$ co $]$ mmunity of the \\
\hline ['Iov- $]$ & {$[\mathrm{Ju}]-$} \\
\hline 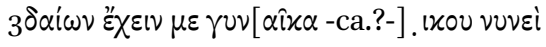 & deans to have me as a wi $[\mathrm{fe} . .$.$] But$ \\
\hline$\delta \varepsilon \dot{\beta}\left[00 \lambda o_{0}-\right]$ & now [he wan] \\
\hline 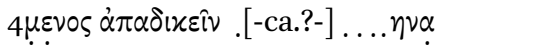 & ts to withhold. ... 100 \\
\hline u... & \\
\hline 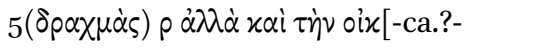 & drachmas and also the $[\ldots$ due $]$ he \\
\hline 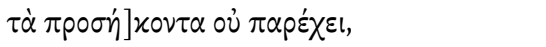 & does not provide. \\
\hline 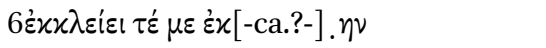 & He shuts me out of $[\ldots]$ me \\
\hline$\pi \alpha \nu \tau \varepsilon \lambda \hat{\omega} \varsigma \mu \varepsilon$ & completely \\
\hline 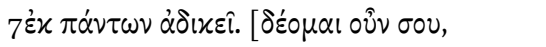 & from everything he wrongs. [I beg \\
\hline$\beta \alpha \sigma ı \lambda \varepsilon \hat{v}, \pi \rho \circ \sigma \tau \alpha^{\prime} \xi \alpha ı \Delta เ \circ \varphi \alpha^{\prime} v \varepsilon ı \tau \hat{\omega} \iota$ & you therefore, my king, to order \\
\hline 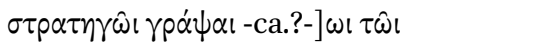 & Diophanes, the strategos, to write to \\
\hline$\dot{\varepsilon} \pi l \sigma \tau \dot{\alpha} \tau \eta$ & ...] the epistates \\
\hline 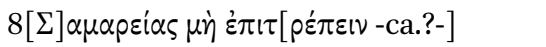 & of Samareia not to let ... to send \\
\hline 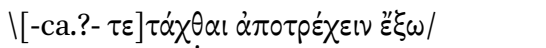 & Jonathan \\
\hline
\end{tabular}

'I $\omega \nu \alpha \theta \dot{\alpha} \nu \dot{\alpha} \pi \circ \sigma \tau \varepsilon \hat{\imath} \lambda \alpha l$

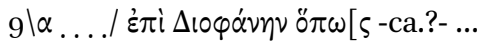

To Diophanes in orde $[\mathrm{r} . .$.$] ...$

\footnotetext{
42 See the critical remarks by Schenker, "Übersetzung," 24-25.

43 As suggested by Rajak, Translation and Survival, 85 .

44 This would be expected if the introduction of the different legal structures took place in the second century вСЕ: see Honigman, "Ptolemaic Definitions," 43-44.

45 I am following the transcription of the text from http://papyri.info/ddbdp/p.enteux;;23.
} 
Mélèze Modrzejewski understands the situation as follows: the Judean husband (Jonathan) has divorced his wife (Helladote) on the basis of Deut 24:1-4, which grants the husband the sole right to initiate a divorce, "sending her out of the house." ${ }^{46}$ Now the wife, whom Mélèze Modrzejewski conceives as nonJudean because of her Greek name (a debatable presupposition given the frequent appearance of Jews with Greek names), appeals to the king on the basis of Greek custom, which accords husband and wife equal rights, and which she

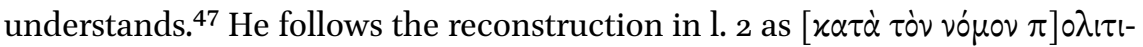
xòv $\tau \hat{\omega} v$ ['IOv] $\delta \alpha i \omega v$ from $C P J$, which $C P J$ translates as "in accordance with the law of the Jews." Yet Mélèze Modrzejewski goes one step further and interprets vópov $\pi$ ] $\partial \lambda$ iाxòv $\tau \hat{\omega} \nu$ ['Iov] $\delta \alpha i \omega \nu$ to refer to the "Greek Torah."48

Numerous questions arise with this interpretation. First, even if one follows Mélèze Modrzejewski's reconstruction with regard to the situation underlying the appeal to concern a divorce, ${ }^{49}$ there is little indication of a reference to the written Septuagint rather than a more general Judean—or even Greek! oral custom. Tcherikover and Fuks even suggest, "The obligation of the husband not to drive his wife out of the house $(\dot{\varepsilon} \kappa \beta \alpha \lambda \varepsilon \hat{\imath})$ is a usual clause in every marriage contract of the Ptolemaic period." ${ }^{50}$ Therefore, there is not even a necessary reference to Judean custom, even though it concerns the practice of at least a Judean man. Instead, in this case Judean practice mirrors the practice of the broader Ptolemaic law. Furthermore, this mirroring of broader Egyptian custom follows the practice in other Judean communities, such as earlier in Elephantine, where payment was required by the initiator of a divorce-

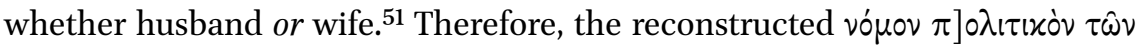
['Iov] $\alpha \alpha_{i}^{\prime} \omega \nu$ - if correct-does not differ from Greek or earlier Egyptian practice. Therefore, the evidence from this fragmentary papyrus does not warrant Mélèze Modrzejewski's wide-reaching conclusion that the practice on display

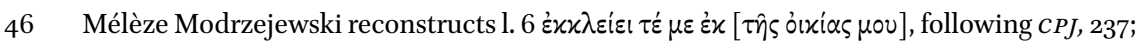

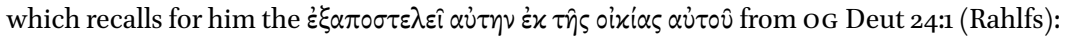
Mélèze Modrzejewski, "Septuagint as Nomos," 195-96.

Mélèze Modrzejewski, Jews of Egypt, 112.

48 Mélèze Modrzejewski, 111.

49 The papyrus is quite fragmentary, and, while this is a viable option, it need not even concern a divorce at all. This in itself would void the appeal to Deut 24 as authoritative. CPJ, $23^{6}-37$, for example, remains more cautious, referring to "family matters: a woman insulted in some way by her husband." One other option might be taking a second wife. See, for example, the clause in Mipțahyah's marital contract with Eshor in Elephantine (TAD B2.6). If Eshoror took a second wife, he was required to pay Mipțahyah twenty karsh of silver. For discussion see Azzoni, "Women."

$50 \quad$ CPJ, 238.

$5^{1}$ See TAD B2.6; B3.3; and B3.8. See also Azzoni, Private Lives, 64-68. 
here indicates a Judean law apart from the practice of the broader culture as something strictly Judean, deriving from a written Torah, even for family law.

In sum, it is possible that Mélèze Modrzejewski's interpretation of an appeal to a Judean nomos with regard to a divorce dispute could be correct, but my analysis reveals a considerable number of questionable assumptions required for his conclusion. Given that this text constitutes a central piece of evidence for his argument, it provides a rather fragile foundation for the house he then constructs. Furthermore, even if one follows his analysis, it does not indicate reference to a written Greek Torah as the basis for the appeal.

A second text often referred to in support of the view that the Greek Torah functioned as Judean civic law is $C P J$ 1.10, a papyrus from the Zenon Archive, therefore from the first half of the third century вСЕ..$^{52}$ This record of brick deliveries notes that on a certain seventh day no bricks were delivered by an individual by the name of Phileas. The entry instead reads "Sabbath" at this point. In conjunction with his discussion of this text, Mélèze Modrzejewski concludes: "We have reason to believe that, by and large, the Jews of Egypt observed the Judaic commandments." ${ }^{53}$ However, his conclusion again rests on a very limited foundation. The text offers data on only a single seventh day, for which $\Sigma \dot{\alpha} \beta \beta \alpha \tau \alpha$ rather than an amount is entered in a column for a single individual, Phileas. This provides evidence neither for a widespread practice nor for any connection to a written nomos functioning as law. It could just as easily concern one individual (or even group), assumedly of Judeans, basing their action on the traditional ethnic custom, though a custom that became increasingly important in the exilic and later periods. ${ }^{54}$ The widespread appearance of names related to the Sabbath among Egyptian Jews mentioned above also supports the significance or even observance of the Sabbath. ${ }^{55}$ However, it does not indicate reference to the written Greek Pentateuch. In other words, while

$52 \quad C P J, 136$. A third text brought in support is $C P J$ 1.133: see Mélèze Modrzejewski, "Septuagint as Nomos," 193. However, nothing in it indicates allusion to the Torah, certainly not to a written Greek Pentateuch.

53 Mélèze Modrzejewski, Jews of Egypt, 112. LeFebvre largely bases a supposed change in status for the Torah at this time on the basis of this and the Helladote divorce papyrus (see above) on Mélèze Modrzejewski's analysis, stating "at least some of the Jews in Egypt learned to use their native written law as a courtroom law code": LeFebvre, Collections, Codes, Torah, 173 .

54 For a detailed discussion on the growing importance of Sabbath, see Grund, Entstehung. The Elephantine data do not clearly support practice of Sabbath in the Persian period as mentioned by Granerød, Dimensions of Yahwism, 208. On the documented rise of the practice of Sabbath in tax records, see Clarysse et al., "Observing Sabbath," 54-55, but this concerns an even later period.

55 On the importance of Sabbath and several other traditional names (especially the patriarchs), see Honigman, "Birth of Diaspora." 
this text and the naming tradition do support the contention that Judeans in Egypt honored the Sabbath tradition, ${ }^{56}$ this practice does not need to refer to a written document and could simply be a practice passed down orally within the Judean community.

Evidence against the import of pentateuchal law appears, on the other hand, in the realm of finance. A specific case arises in CPJ 1.23, which concerns the charging of interest in an agreement between Judean soldiers of the Fayum in 182 B CE. According to this text, Apollonios lent Sostratos copper money, and Sostratos' house served as the underlying security for the loan. If Sostratos failed to repay the debt within a year, then Apollonios could take possession of the house, and 24 percent interest on the loan would accrue. The first year free of interest could be understood as embracing the biblical principle of not charging interest to a fellow "Israelite,"57 but the normal Ptolemaic rate of 24 percent that would begin in the second year shows that the general source for the administration of justice here is found in the royal edicts. ${ }^{58}$

\subsection{Arbitration before Judean Officials: The nomoi patrioi and the Torah/Pentateuch}

As already mentioned above, documentation from the second century ВСЕ explicitly attests to the existence of a Judean politeuma in Herakleopolis that executed or arbitrated legal judgments, primarily for Judeans. ${ }^{59}$ Discussion of the documents shows that some development in terms of overlap with language in the Greek Torah appears, as well as the importance of adherence to the Judean deity, by whom ancestral oaths would be sworn.

A papyrus from among the more recent Herakleopolis finds concerning the Judean politeuma in that location has also been called as support for understanding the Septuagint as Judean "civic law," in this case in 134 вCE. The papyrus in question, P. Polit. Iud. 4, consists of a complaint by a Judean man, Philotas. He was engaged to Nikaia, daughter of Lysimachos, but Lysimachos then married off his daughter to another man without Philotas providing a bill

$5^{6}$ Perhaps even to a greater degree than in Judea, given the comparatively rare occurrence of these names there (see Honigman, "Birth of Diaspora").

57 For discussion of the underlying biblical texts and further bibliography, see Altmann, Economics, 254-59.

$58 \quad C P J, 164 . C P J 1.24$ is difficult to interpret because it concerns an amount from an earlier loan for a business venture, for which interest might be allowed under pentateuchal stipulations, though this is a matter of interpretation. In this case, Judas and Agathokles agreed on a loan at the standard rate of 24 percent interest.

59 The most extensive discussion of these texts appears in Cowey and Maresch, Urkunden des Politeuma. 
of divorce. It is claimed that this deed of divorce was required by Judean law, ${ }^{60}$ yet this custom does not appear in the Pentateuch for an engaged couple, but only in later material. The Torah itself only deals with the situation of a husband rejecting his wife after marrying her, and, according to the translation in

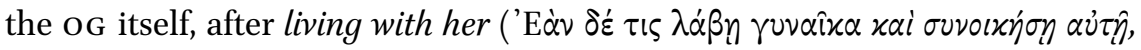
Deut 24:1). This phrase contrasts with MT ובעלה , "and rules over / married her." While one common rendering for the verb בעל , בעל, the Greek term understands marriage according to Egyptian custom in which a marriage is consummated through living together. ${ }^{61}$

Thus, the text of the MT and especially the og indicate that the Septuagint hardly served to support Philotas' complaint. The og version in fact undermines Philotas' claim even more because he never lived with the woman. Perhaps one could argue that Philotas-or rather the scribe writing the appeal — attempts to extend the purview of the Septuagint to include this situation, but such a contention is an argument from silence.

There is overlap in some terminology, namely the $\beta i \beta \lambda$ iov $\dot{\alpha} \pi \circ \sigma \tau \alpha \sigma i o v$ in the papyrus (ll. 23-24), which only otherwise appears in biblical material, e.g., Deut 24:1, $3 \cdot{ }^{62}$ Therefore, the language of the OG coincides and may begin to influence verbal formulations in Judean legal settings. ${ }^{63}$ However, the difference in

6o Cowey and Maresch, 56. A small number of deeds of divorce also appear in Egyptian tradition, as noted by Manning, "Demotic Law," 837. Other Judean divorce deeds come from the Roman period, including CPJ 2.144 from 13 BCE in Abusir el-Meleq, Egypt. The earliest attested mentions in Palestine appear in Aramaic (גט) in the first two centuries CE (Masada and Papyrus Șe'elim 13): for discussion see Ilan, "Divorce Bill." Several are issued by the wife, showing that following the literal interpretation of Deut 24 did not take place in these later settings either.

61 Lippert, "Egyptian Law." On the further appropriation of marriage customs found in the Ptolemaic Egyptian milieu, see Kugler, "Uncovering Echoes," 149.

62 Also in Isa 50:1 and Jer 3:8. Another term that agrees with Septuagint terminology appears

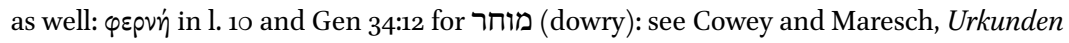
des Politeuma, 64 .

63 Though it could also simply indicate common Greek terminology picked up by the translators of the Pentateuch into Greek. A similar situation arises with regard to several other terms: see Cowey and Maresch, 16; with more extensive discussion in Kugler, "Uncovering Echoes." Both some verbal resonances but also the thematic shape of the underlying concern in P. Polit. Iud. 7 may reveal commitment to "Torah ethics" (esp. Lev 25:35-38), though within the broader scope of Greek legal categories for family law: see Kugler, "Dorotheos Petitions." Note here as well, however, that the allusions do not cite biblical texts in a direct judicially authoritative manner, leaving the biblical conceptions as influential but not of practical judicial authority. On this helpful distinction see Vroom, Authority of Law, 19. In fact, Kugler's analysis agrees with the emphasis of the Letter of Aristeas and the literary texts I discuss below of the ethical and philosophical importance for the Pentateuch. Other allusions put forward by Kugler for P. Polit. Iud. are less convincing. For example, he 
the precise setting from the specific statement-enhanced in the OG version of the biblical statute-indicates divergence between the biblical text and the situation into which Philotas attempts to assert his complaint. His letter provides no evidence of living with the woman and instead indicates the opposite; therefore, the biblical statute did not apply. In ll. 14-15 and 3o, Philotas does refer to a nomos, according to which the agreement was concluded and that should provide the basis for the archontes (leaders) of the politeuma to judge. Thus, some legal conception is at play, but whether it is custom or law-oral or written-remains unclear. Though the language mirrors the Septuagint, the application does not. ${ }^{64}$

Another kind of possible connection to the Greek Torah also arises in these papyri. Throughout the papyri one finds mention of the swearing of an oath, specifically an "ancestral oath," öpxos $\pi \dot{\alpha} \tau p 10 \varsigma$, or similar formulation in P. Polit. Iud. 3.28-29, 9.7-8, and 12.10. This feature of the texts is significant in two ways. First, the oath would be sworn by a particular deity, and in this case one can assume YHWH, thus bringing a religious/cultic aspect into the legal sphere. Second, it has been argued that the closest philological link for such promissory oaths appears in Num 30:3. ${ }^{65}$ Thus, certain verbal and conceptual overlap with the Septuagint can again be detected.

However, like in the earlier material, a loan agreement from the Herakleopolis politeuma (P. Polit. Iud. 8) diverges from any connection to the Pentateuch. Though this dispute happens between Judeans and the petition is made to Judean leaders (archontes), which would have more reason to base decisions on a written Greek Pentateuch, in P. Polit. Iud. 8, a mortgage agreement includes 24 percent interest! Thus, no basis in pentateuchal law appears

suggests that P. Polit. Iud. 1 (1. 11-13) has Deut 25:1 in mind because both have $\alpha \nu \tau \imath \lambda \circ \gamma$ i $\alpha$ and $\dot{\alpha} \sigma \chi \eta \mu o v \varepsilon \dot{\varepsilon} \omega$ for an offence of honor (Kugler, "Uncovering Echoes," 146). However, P. Polit. Iud. 1 actually contains $\alpha \mu \varphi \imath \lambda o \gamma i \alpha \nu$, a rare synonym. Likewise, the connection between P. Polit. Iud. 6 and Exod 21:20-21 (Kugler, "Uncovering Echoes," 147) is quite weak, as is his contention that $P$. Heid. Inv. G 5100 has anything to do with the rulers of the Judean politeuma: see esp. Kugler, "Uncovering New Dimension." Nonetheless, I find his project of identifying notions of the mixing of Ptolemaic koine and Torah traditions quite important, yet perhaps less so for the application of judicial statutes as positive law, which instead may misunderstand the conception of Torah in these Judean communities.

64 Perhaps, as Moore claims, it was the letter's scribe that had some familiarity with the Septuagint and thus adopts its language. This remains an option, but it does not indicate that the Greek Torah serves as the adjudicatory basis for the legal complaint: see Moore, Jewish Ethnic Identity, 85 .

65 Similarly Moore, 91-94. The term does not otherwise appear in the papyri, but it is found in Num 30:3. 
in the sphere of economic contracts, which instead use customary Ptolemaic interest rates. ${ }^{6} 6$

\subsection{Summary of the Papyrological Material}

These are the main pieces of evidence put forth in the scholarly discussion in support of the written Greek Pentateuch functioning as the civic law in Ptolemaic Greek courts or in Judean politeumata. Neither as individual documents nor as a group do they indicate that the written Pentateuch functioned as a basis for legal decisions or administration of Judean legal disputes in thirdcentury Ptolemaic Egypt. ${ }^{67}$ Instead, in judicial matters, Judeans seem largely to assimilate practices found in the broader host culture for use in their own community. ${ }^{68}$ In fact, the references to the ancestral oaths take place while simultaneously adopting common Ptolemaic legal practices. The result is that the only possible positive evidence concerns marriage/divorce, Sabbath observance, and oath-taking, all of which could easily be governed by oral customary traditions with a much looser connection to written Pentateuchal texts. ${ }^{69}$

Some tantalizing evidence for the influence of the Greek Torah begins to take shape in the second-century Herakleopolis material. However, even where the formulations may imply some familiarity with the verbal constructions in the Greek Torah, little evidence exists for references that show detailed knowledge of the Pentateuch in judicial complaints. ${ }^{70}$ The best example, that of the "certificate of divorce," even misses a key element that renders the text alluded to (Deut 24) invalid for the case at hand.

Furthermore, some documented evidence contradicts pentateuchal stipulations. While legal validity does not imply that members of the polity always follow the law, ${ }^{71}$ it still remains surprising that no direct appeals to pentateuchal statements appear in the extant corpus of papyri if it indeed was the well-known basis for the arbitration of legal disputes by the Judean leaders of

66 A number of other possible references from the papyri to the Septuagint are discussed and largely rejected by Moore, $83-86$.

67 On a broader level, the establishment of the Judean temple in Leontopolis by Onias, reported in Josephus, Ant. 13.72, shows that the Deuteronomic claim for a single sanctuary (esp. Deut 12) was not authoritative in literal terms at this time or place, at least with regard to the divine choice for a sanctuary in the land of Israel.

68 See Czajkowski and Wackenier, "Legal Strategies." Thanks to the authors for sharing their article with me prior to publication.

69 For a similar, if somewhat more sanguine conclusion, see Moore, Jewish Ethnic Identity, 76.

70 Given that the language of the Lxx itself was influenced by the Greek in its environment, it is also possible that $\beta \_\beta \lambda$ iov $\dot{\alpha} \pi \circ \sigma \tau \alpha \sigma i o v$ even originated from Hellenistic judicial contexts, though no positive evidence supports this contention.

As argued by Hart, Concept of Law, 111-15. 
the politeuma. Such an appeal was made to a royal decree in a local judicial procedure, so such a practice was an option in the Ptolemaic setting. Such a case develops with regard to the financial issue of interest, which, though an agreement takes place between two Judeans, operates on the basis of Ptolemaic rather than pentateuchal practice in a Judean setting. This document indicates either no knowledge of, or practical legal disregard for, the Torah prescriptions.

In these records, rather than having the Greek Torah in view, a situation more like the Judean colony Elephantine in the Persian period obtains. Some traditions have considerable influence, yet, even if some familiarity with the pentateuchal writings did take place, which may be one step further than in Elephantine, the Greek Torah does not provide legal statutes.

The situation instead points to a slow dissemination of the (Greek) Pentateuch. Judeans in Ptolemaic Egypt conducted their legal affairs with a general notion of Judean tradition in mind, supporting that very rendering for vóno $\pi \dot{\tau} \tau p ı$ เ: "ancestral customs," especially for the third-century papyrological documents. ${ }^{72}$ The general situation in Ptolemaic Egypt for the Greek Torah calls for viewing these writings more as something of a "cherished tradition," which exercises influence, but does not function as statutory law. Specifically, the appearance of similar language to the Septuagint in secondcentury Herakleopolis raises questions for the Greek Torah's relationship to other Hellenistic-Judean documents—-those of a more literary nature.

\section{The Divine Torah in Ptolemaic Egypt}

This paucity of evidence for the importance of the Greek Pentateuch among the mundane written legal Judean documents in Ptolemaic Egypt is strikingly different from some of the contemporary literary sources, especially the Septuagint itself and a variety of Hellenistic-Judean sources. ${ }^{73}$ Generally speaking, it points to a different kind of significance for the Torah in these settings.

The general meaning of vópos - including not only the broader notion of "custom" but also the written Torah-may provide a bridge for an important aspect of the development of "divine law" within early Judean communities. The contrast between the practices attested in the mundane legal texts and

72 The term vónos in singular or plural appears in relevant contexts in Let. Aris. 31, P. Polit. Iud. 4.14-15, 30; 9.29. This corresponds with conceptions of Judean law and custom in Esther.

73 Note also the various versions of Esther, Daniel, and Maccabees, which I plan to address in other publications. 
the significance placed upon law-especially divine law - in biblical and literary texts from the period gives rise to the questions of the nature of the significance of the appearances of vópos, especially in connection with God, in Hellenistic-period biblical and literary texts.

\subsection{Septuagint}

The most important contribution to the rise in significance of the divine Torah in the Ptolemaic period comes in the very act of translation of the Pentateuch into Greek. The earliest manuscript evidence for the Greek text comes from the second century в СЕ, which points to the likelihood of the third century for the time of the translation. ${ }^{74}$ Furthermore, a number of Egyptian loan words and terms connected with Ptolemaic Egypt suggest Egypt for the likely location of translation. ${ }^{75}$

Interpreters propose a number of different theories regarding the purpose and circumstances surrounding the achievement of this translation. ${ }^{76}$ In any case, it does represent an accomplishment, perhaps the first translation rather than indirect retelling of a group's foundational document, contrasting with, for instance, Manetho's Aegyptica, Berussos' Babyloniaca, and Artapanus' History of the Jews. ${ }^{77}$ I interpret this evidence of the fact of the translation itself as an important indication of the authority attributed to the Pentateuch within (some) Hellenistic-Judean communities. However, one question that arises is the nature of this authority: was it primarily conceived in legal, philosophical, identity-political, historical, or other terms? The Greek Torah itself does not offer a ready-made answer to this question. Instead, the Hellenistic-Judean literary sources from the Ptolemaic period may offer some insight, to which the next section turns.

\subsection{Literary Sources}

A considerable number of Hellenistic-Judean literary sources come down through Josephus, Clement of Alexandria, and Eusebius, often by way of Alexander Polyhistor, who lived in the first half of the first century ВСE, thus providing a terminus ante quem for his sources. ${ }^{78}$ In addition, around twenty medieval manuscripts of the Letter of Aristeas are attested (which supplement

74 In addition to the Prologue of Ben Sira 7, there is 4 QLXXLeva, 4 QLXXNum, Pap. Fouad 266, and Pap. Rylands Gk 458. Cf. Kreuzer, "Torah to Nomos," 13.

75 For a list of features see, e.g., Joosten, "Language as Symptom."

76 For an overview see, among others, Kreuzer, "From Torah"; Dorival, "New Light"; Schenker, "Übersetzung."

77 This has been noted by Schenker, $27-28$.

78 Weber, Gesetz, 37. 
the sections found in Josephus and Eusebius). In these sources, most of them fragmentary and likely hailing from the third and second centuries BCE, small references to the divine nature of specific pentateuchal commands appear, often to particular commands consistent with the identifiers of Judean ethnicity in the late Hellenistic and Roman eras-dietary prescriptions (Letter of Aristeas), circumcision (Theodotus), and Sabbath (Agatharchides) —along with celebration of Passover (Ezekiel the Tragedian). ${ }^{79}$

A considerable number of these early Judean sources, though often fragmentarily preserved in Christian sources, show little legal interest in the Pentateuch. For example, the fragments of Artapanus in Eusebius (Praep. ev. 9.18, 23, and 27) and Clement (Strom. 1.23.154) focus on the narrative portions of Genesis and Exodus - with embellishments - dealing with Abraham, Joseph, and Moses. Pointing to an Egyptian setting, ${ }^{80}$ Artapanus apparently intends to show the superiority of the Israelites, but he does not do this by means of their reception of a law, much less a divine one (contra Deut 4:5-8). He instead depicts the biblical heroes as bringers of various bits of culture (e.g., Abraham teaching astronomy) to the Egyptians. ${ }^{81}$

Fragments attributed to Demetrius (also Praep. ev. and Strom.), from the third century вСЕ, likewise address the narratives of Genesis and Exodus in their Greek version..$^{82}$ As such, it provides an important confirmation that an Egyptian Judean community had considerable knowledge of details of the Greek Torah. However, this intricate familiarity does not attest to interest in judicial application. Rather, in this case the author attempts to deal with issues that might arise with regard to the chronology or other gaps of various events in the process of reading the narratives. In sum, the extant fragments of the work are neither concerned specifically with the divine origins ${ }^{83}$ nor with the legal application of the Pentateuch, but rather with answering potential exegetical problems. As such, it bolsters the validity of the biblical material, though more as an authoritative source concerned with cultural history than legal superiority or divine origin.

79 These practices also take on the status as identity markers within the pentateuchal narrative itself.

$80 \quad$ Collins, "Artapanus," 891, and Weber, Gesetz, 6o.

81 Somewhat similar is the work of Eupolemus likely in the mid-second century BCE, but in Palestine, who also argues for the supremacy of Judean culture because its heroes invented various cultural technologies, in this case, however, the invention of both (phonetic?) writing and laws are attributed to Moses: frag. 1, in Eusebius, Praep. ev. 9.26.1.

82 This is apparent from the 430 years spent in Canaan and Egypt (OG), which leads to the 215 years in Canaan and 215 in Egypt in Demetrius frag. 2 (Praep. ev. 9.21.16-18) vs. 430 years in Egypt alone (MT); Weber, Gesetz, 44 n. 5 .

83 At most it calls the Torah "the sacred book" in frag. 4 (Praep. ev. 9.29.15). 


\subsubsection{Theodotus}

In terms of positive evidence for legal conceptions, one may turn to Theodotus. His epic poetry is also recorded in Eusebius, in Praep. ev. 9.22.4-7. There is some debate on its provenance-Judean or Samaritan - and it was likely written before 15 о ВСе. ${ }^{84}$ His poem refers to two important elements, one significant for a legal conception of the Pentateuch and another for its divine origins. First, retelling the narrative of Gen 34, as a response to Hamor's request for Dinah to marry his son, Theodotus states:

Concerning the necessity of their being circumcised, Jacob says, "For this

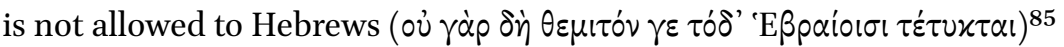
to bring sons-in-law or daughters-in-law into their house from elsewhere but, rather, whoever boasts that he is of the same race."

EUSEBIUS, Praep. ev. 9.22.6

This notion of "allowing" does not appear in the oG or MT, which gives as a

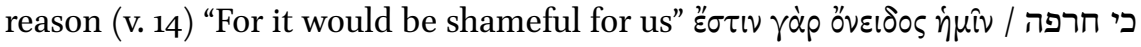
הוא לנו. In other words, while remaining in the realm of group identity, a slight shift occurs, removing the concern from honor and shame to that "allowable by law." ${ }^{86}$ Therefore, Theodotus attests to a legal framing for prohibited and acceptable actions on the part of Jacob's family.

The importance of a legal point of view comes through even stronger in frag. 5 (Praep. ev. 9.22.7), where Jacob continues to comment on circumcision, declaring

Once (God) himself, when he led the noble Abraham out of his native land, from heaven called upon $\left(\chi^{\prime} \lambda \varepsilon \sigma^{\prime}\right)^{87}$ the man and all his family to strip off the flesh (i.e. the foreskin), and therefore he accomplished it. The command remains unshaken, since God himself spoke it ( $\dot{\alpha} \sigma \varepsilon \mu \varphi \dot{\varepsilon} \varsigma$

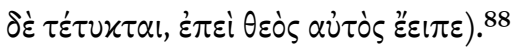

Here Theodotus recalls the eternal covenant (ברית עולם, vv. 7, 14) to Abraham in Gen 17 signified by the circumcision of the males in Abraham's household.

\footnotetext{
84 For discussion see Fallon, "Theodotus," $785^{-88 .}$

85 Greek text taken from Stearns, Fragments, 103.

86 This follows the definition for $\theta \varepsilon \mu \iota \tau$ ós in LSJ: "allowed by the laws of God and men, righteous."

87 A poetic indicative form of $\chi \varepsilon \lambda \varepsilon \dot{\omega} \omega$, which LSJ renders "to urge or drive on, urge, exhort, bid, command, order." The Greek text follows Gifford, Eusebii, 15:538

88 Translation from Fallon, "Theodotus," 792.
} 
However, no mention of a covenant appears; God instead issues a command. While the substantive object "command" remains implied (it is inserted into the translation for comprehension), this interpretation only requires referring to God's antecedent commanding in the previous clause. As a result, Theodotus views the command of circumcision within the category of divine positive law: something authoritative because it originated from God and meant to be obeyed by those of Abraham's descendants-in this case any of the Shechemites - wishing to join Jacob's household. In other words, Theodotus attests to the firm nature of the command, founded as it is in the divine utterance and therefore something obligatory for Abraham's descendants.

\subsubsection{Aristobulus and Orphica}

Eusebius and Clement also refer in several places to the work of Aristobulus, who was purportedly one of the seventy involved in translating the "divine and sacred scriptures of the Hebrews": the Septuagint. However, his work likely comes from the mid-second century вСе in Alexandria. ${ }^{89} \mathrm{He}$ is then said to have written exegetical books on the law of Moses, and his work orients itself to the text of the Greek Torah, ${ }^{90}$ which demonstrates the acceptance of the authority of the Greek Pentateuch, while implying the need for its interpretation.

One example of his exegesis comes in Eusebius' Hist. eccl. 7.32.16-18. and concerns the date for the celebration of Passover ${ }^{91}$ - thus a very concrete application of biblical law, yet law addressing the cultic sphere and central to Judean identity rather than some kind of judicial dispute (cf. Exod 12:43-49; Num 9:13-14).

A further example appears in Eusebius, but this time in Praep. ev. 8.9.3810.17, in this case arguing for a metaphorical understanding of the body parts attributed to God, especially in narrative sections of Exodus (following the OG). Aristobulus directly names Moses as the legislator (8.10.3, cf. 8-9), whom he proclaims as a prophet through "wisdom and divine spirit" (8.10.4). In these contexts, then, "law" includes narratives, even those such as Exod 3 and Gen 28 (in frag. 2, Praep. ev. 8.10.8-9) that do not include positive law. In any case, Aristobulus continues by mentioning the (Sinai) mountain event, emphasizing that God's descent upon the mountain intends to show that the law comes

$89 \quad$ Following Collins, "Aristobulus," 833. Placed in the first half of the second century by Weber, Gesetz, 311.

9o Weber, 99, esp. n. 23 .

91 This is also a concern in the Persian-period Elephantine papyri. 
through the action of God (8.10.12), thus providing it with combined divine and human associations.

Aristobulus also labors to show how the truth of the biblical revelation of the Sabbath receives support both from natural law and from Greek tradition (Homer and Hesiod). Mention is made of the binding nature of the Sabbath: "And the legislation has shown plainly that the seventh day is legally binding for us as a sign of the sevenfold principle which is established around us, by which we have knowledge of human and divine matters" (Praep. ev. 13.12.12). ${ }^{92}$ Like the interpretation in Let. Aris. 171, Aristobulus too argues that the biblical practice agrees with natural law (Praep. ev. 13.12.9). Thus, even when addressing a positive customary law, the emphasis for the Egyptian Judean author lies on its philosophical and rational significance, ${ }^{93}$ rather than its judicial importance.

Aristobulus also turns to an even earlier source, Orphica, which represents a tradition of esoteric instructions given by Orpheus to Musaeus and bears witness to conceptions of divine law in Judean communities. While there is a complex textual tradition for Orphica, the "long" version, found in Eusebius' Praep. ev. 13.12.2, conceives of God as a legislator:

1 I will sing for those for whom it is lawful, but you uninitiate, close your doors,

2 Charged under the laws of the Righteous ones, for the Divine has legislated ${ }^{94}$ $\cdots$

6 But look to the divine word, study it closely EUSE BIUS, Praep.ev. 13.12.2

This quote functions as a statement of Aristobulus' purpose, indicated in his comment prior to the quotation of Orpheus that Plato and Pythagoras benefitted from earlier translations of the Judean law (Praep. ev. 13.12.1), thereby showing the superiority of Judean law by its temporal priority. However, a further motivation embedded in the text consists of showing that the Greek philosophers are on the right track in seeking the divine through the contemplation of nature, reporting that they "hear the voice of God," which Aristobulus relates to God's speaking the world into being (13:13.3-4; cf. Gen 1).

92 Translation from Collins, "Aristobulus," 842.

93 Similarly, Weber, Gesetz, 105.

94 Alternatively: "The law divine announced to all mankind," according to Gifford, Eusebii Pamphili, 719. 
Generally speaking, Aristobulus works here as an apologist to show the Pentateuch's superiority to Greek wisdom, which itself was derived from the Judean law. However, it is important to note that he accepts Hellenistic philosophical values and defends the Pentateuch within that framework. ${ }^{95}$

\subsubsection{The Letter of Aristeas}

Returning to my opening discussion, the Letter of Aristeas offers the most stunning statement on the divine nature of the Pentateuch in a Ptolemaic Egyptian setting. Unlike the papyri, the Letter of Aristeas puts the Pentateuch in direct focus for the Alexandrian Judean community, making a lengthy argument primarily for its philosophical and cultic — not legal—significance. Emphasizing these categories indicates that the importance the author placed on the Pentateuch's divine connection did not directly link to any judicial conception.

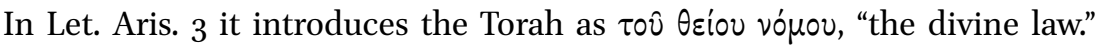
Then, as mentioned above, Let. Aris. 31 mentions the Judean nomos as $\tau \dot{0}$ xai

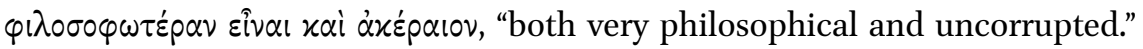
These descriptors provide the essential conceptual categories through which the Letter of Aristeas views the Pentateuch. A considerable portion of the Letter of Aristeas seeks to unfold this "very philosophical" nature of the Pentateuch, doing so by addressing a section of the Pentateuch that appears decidedly nonphilosophical: the dietary laws (Let. Aris. 128-171). ${ }^{96}$ Perhaps the most direct example comes in Let. Aris. 144:

Do not come to the exploded conclusion that Moses legislated these matters on account of a curiosity with mice and weasels or similar creatures. But everything has been set in order solemnly for pure investigation (årviेv $\varepsilon \pi i \sigma x \varepsilon \psi(v)$ and the outfitting of character for the sake of justice. ${ }^{97}$

Let. Aris. 144

Here, at the outset of some detailed comments on the dietary prohibitions (Lev 11//Deut 14), which both pentateuchal texts describe as being for the purpose of setting the Israelites apart to YHWH but without providing a deeper "rational" explanation for the specific choices of these animals, ${ }^{98}$ the Letter of Aristeas suggests that just such an explanation exists. It pertains

95 Also Collins, Athens and Jerusalem, 188.

96 For a thorough discussion of the dietary laws in the Letter of Aristeas, see Angelini, "Reception and Idealization."

97 Translation from Wright, Letter of Aristeas, 271. Italics added. Cf. Honigman, "Jews as Best," 216.

$98 \quad$ For discussion see Altmann and Angelini, "Purity, Taboo, Food." 
to the spheres of science, ethics, and justice. The use of the rather rare term $\varepsilon \pi i \sigma \varkappa \varepsilon \psi(v$, , "investigation," indicates an outsider's point of view. As a result it is appropriate for a rational or philosophical inquiry, ${ }^{99}$ with less emphasis placed on the material foodways themselves. The second goal of the Mosaic dietary prohibitions lies in their leading to virtue-again a supreme Greek philosophical value (also Let. Aris. 127, 160).

Furthermore, in this section it is a "pure" ( $\dot{\alpha} \gamma$ ós) investigation-a descriptor often found in the cultic realm, and one of a number of modifiers of the Torah belonging to the cultic realm in the Letter of Aristeas. ${ }^{100}$ Yet, as seen in this passage, Honigman notes, "the way they are contextualised in the text systematically shifts them to the realm of Greek philosophical speculations about the divine." ${ }^{101}$ So, given its superior philosophical character, in Let. Aris. 38 the king proposes to the Jerusalem high priest—addressed as his equal and therefore also a ruler - to make a translation of the Judean law that will take its place among the "other royal books" of the Alexandrian library.

Another instance in which the Letter of Aristeas elevates the Pentateuch to divine status is in Let. Aris. 177, where King Ptolemy prostrates himself before the Torah scrolls - a gesture reserved for deities in Greek culture ${ }^{102}$ - and refers to the Pentateuch as God's "utterances" $\left(\lambda o^{\prime} / \alpha\right)$. The Letter of Aristeas thereby conceptualizes the Torah as divine and, therefore, as the best nomos among all human nomoi. Because it is divine, it displays the most elevated kind of human nomoi, which generally differ from culture to culture. This diversity is on display in the different eating customs (nomoi) at the Ptolemaic royal banquet, where each ethnic custom is respected, showing that such customs are not universal. However, the Judean nomos concerning dietary prohibitions represents the rational divinity of nature (physis), for this culture's nomos accords with nature (Let. Aris. 171: "Thus I am persuaded, O Philocrates, to clarify for you, because of the love of learning that you possess, the utmost dignity and

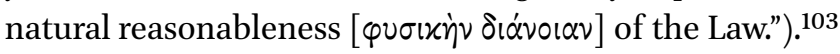

Finally, the narrative of the completion and reception of the translation in Let. Aris. 307-313 underscores the divine nature of the Pentateuch and

99 On this term cf. Xenophon, Oec. 8.15 for "looking over" the stores in a ship; also Plato, Leg. 849a; of "supervising" a temple. The idea concerns supervising or getting an overview.

100 Translation from Wright, Letter of Aristeas, 142.

101 Honigman, "Jews as Best," 215. She notes: $\theta \varepsilon \hat{\imath} 0$ L Let. Aris. 5 (cf. 31, 313) as in $\sigma \varepsilon \mu \nu \eta े \nu ~ \nu ० \mu \circ \theta \varepsilon-$

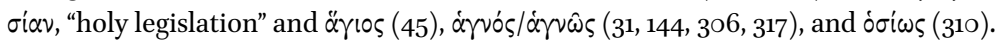

102 For discussion see Wright, Letter of Aristeas, 317-18.

103 Cf. Let. Aris. 143: "For in general all things are to natural reason similar, being managed by a single power, and for each single thing there is a profound reason that we abstain from the use of some of them." And on this section, Wright, 269-70. 
especially its translation. First, while less explicit than in the later versions of the story (e.g., Philo), Let. Aris. 307 implies divine intervention in the work of the translation in the work just "happening" to be completed in seventy-two days (by the seventy-two translators), "appearing as if this circumstance happened according to some plan."104

The section on the reception of the Greek Torah by the Judean community and Egyptian king presents, as argued by a number of scholars, an analogous scene to the exodus narrative that moves from liberation to the promulgation of the Law on Sinai/Horeb for Israel. ${ }^{105}$ Unlike at Sinai/Horeb, the act of liberation takes place in the Letter of Aristeas at the order of the king, rather than against his will (Let. Aris. 15-27). However, similar to the biblical tradition are both the affirmation of the translation by the Judean politeuma and other leaders of Alexandria by standing (Let. Aris. 310; cf. Exod 24; 2 Kgs 23:2; Jer 36; Neh 8) and the statement that it should not be changed (Let. Aris. 311; Deut 4:2; 13:1 [Ет: 12:32]).

Crowning this section is Demetrius' answer to the king about why Greek writers had not mentioned the Torah, given its exceptional nature. Demetrius replies, "Because the legislation is holy and has come about through God, and God struck some of those who did undertake it, and they ceased the attempt" (Let. Aris. 313). ${ }^{106}$ The holiness of the legislation was mentioned earlier, and its divine stature-given the divine involvement in its production-was on display in the amount of time it took and the similarity of its promulgation to the exodus events. However, a new element is introduced in God's protection of translations of the Pentateuch from improper application. Examples are given in Let. Aris. 314-316 of two Greek authors, Theopompus and Theodectes, whom God strikes with illness in order to keep them from inserting Greek translations of the Pentateuch into their works. These contexts were unworthy of such sacred material, nor did the authors possess the prerequisite piety for the endeavor. ${ }^{107}$

Returning to the specific inquiry of this essay, according to the Letter of Aristeas, the divine attributes of the Greek Pentateuch — and therefore by

\footnotetext{
104 Translation following Wright, 434. Furthermore, Wright $\left(43^{6-38)}\right.$ argues that the use of

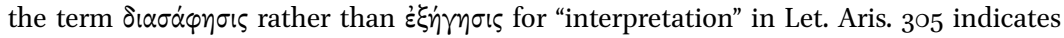
God's approval of the work.

105 Orlinsky, "Septuagint"; Honigman, Septuagint, 37; Hacham, "Letter of Aristeas"; Wright, Letter of Aristeas, 439; Wright, Praise Israel, 284-85.

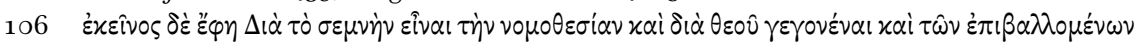

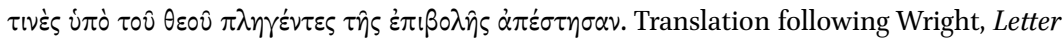
of Aristeas, 441.

107 For similar analysis see Wright, 447-48; Honigman, Septuagint, 6o-63.
} 
implication its Hebrew Vorlage as well-consist of its holiness in the sense that handling it, in this case translating and interpreting it, requires a certain amount of piety. Furthermore, the Letter of Aristeas relates the divine nature of the Greek Pentateuch to the nature of the community receiving it: the Septuagint is only proper for a pious group. By extension, the Letter of Aristeas does not envision the Greek Pentateuch as necessarily appropriate for adjudicating mundane legal matters. It is instead intended for those in search of wisdom and godly living, thereby participating in fundamental aims of Greek philosophy.

This investigation into the role of the Pentateuch in Ptolemaic Egypt gives rise to one overarching conclusion: The most direct references to the Torah conceive of its importance in philosophical terms and group affiliation rather than judicial categories, even when some conception of God as a divine legislator emerges. The general silence from Ptolemaic Judean legal settings with regard to the Greek Pentateuch is striking. For while there is evidence of reference to specific royal Ptolemaic edicts as the basis for a judicial complaint, no such direct pointer toward the Greek Torah appears in Judean judicial settings. Other than a minor appearance of shared terminology in a marital conflict that does not, however, accord with the provisions of Deut 24:1-4 (esp. OG), explicit reference to pentateuchal law remains absent from legal contexts in Ptolemaic Egypt. Oblique references to the Genesis ancestors in names and to Judean traditions like Sabbath arise, but the transmission and observance of such traditions hardly require anything like a written Greek Pentateuch. Arguments can be made for some further allusions or shared terminology, yet the very indirect nature of these connections indicates the distance between the administration of justice among Egyptian Judeans and the Greek Torah.

The Pentateuch and its traditions do appear in literary contexts associated with Ptolemaic Egypt in the third and second centuries BCE. In these documents and fragments, the traditions of the Pentateuch and the pentateuchal texts themselves are conceived as providing the means or basis for Judeans to understand themselves as an identifiable group-Judeans-in Egypt on the basis of some shared practices emerging from shared traditions. For one, they should practice the divinely commanded rite of male circumcision according to Theodotus. And, taking a step further, the cryptic verses of Orphica speak directly of a divine law, but the context uses this image as a way to separate between the initiated and those on the outside. Finally, the Letter of Aristeas 
provides an extended argument for Judean self-understanding by maintaining pentateuchal precepts as exemplary in terms of Greek philosophical rather than any type of judicial conception. ${ }^{108}$ Perhaps one can conclude that, at least in these circles, torah $=$ nomos $=$ custom . Therefore, reception of the Pentateuch that connects it directly with legal administration or adjudication of civil cases must instead focus on a different corpus and geographical setting, likely to appear on Judean soil.

To draw broader implications, it appears that Judeans on foreign soil formulated their general conception of the pentateuchal traditions and writings with which they interacted more as a reference point upon which one might recur both in terms of marking out and solidifying one's social networks (ethnicity) and cultic commonalities that transcend the specific places such as the practice of Passover in Aristobulus (identifying them as "diasporas") and times (through claims to shared histories). ${ }^{109}$ The "laws" of the Pentateuch do not function as legal statutes. They follow the repeated emphasis in Deuteronomy that its statutes are for the time when one is "in the land" (e.g., Deut 12:1). Yet if Deuteronomy prescribes its rules for life in the land, then it also raises the logical question of their authority and appropriateness for concrete application by members of Judean communities outside the land. If one can accept Hacham's proposal that the Letter of Aristeas seeks to provide a foundational affirmation of Judean residence in Egypt despite Deut 17:16's warning to an "Israelite" king not to return to the land of Egypt, ${ }^{110}$ then the letter indicates a certain wrestling with the application of the Greek Pentateuch or its traditions for mundane life in Egypt (and elsewhere). At least in the community related to the Letter of Aristeas, the dietary prohibitions maintain their importance because of their ethical quality but especially the pentateuchal laws concerning loans remain unknown or neglected. In other words, in such cases, the "ordinances and statutes" require negotiation ${ }^{111}$ in order to determine their applicability for defining "who is Israel?" (to take up the verbiage of Deuteronomy) or "What does it mean to be Judean?" (in Hellenistic-Judean circles).

\footnotetext{
108 Collins sees no "common underlying attitude" toward law: Athens and Jerusalem, 158.

109 I am attempting to flesh out the reductionistic term "identity": see Brubaker and Cooper, "Beyond 'Identity."

110 Hacham, "Letter of Aristeas," 14.

111 As seen, from an earlier era, in the correspondence between the Yahwistic community in Elephantine and their compatriots in Yehud and Samaria in TAD A.4.7, 4.9, and 4.10.
} 


\section{Bibliography}

Aitken, James K. “The Language of the Septuagint." In Jewish-Greek Tradition in Antiquity and the Byzantine Empire, ed. James N. Carleton Paget and James K. Aitken (Cambridge: Cambridge University Press, 2014), 120-34.

Altmann, Peter. Economics in Persian-Period Biblical Texts (Tübingen: Mohr Siebeck, 2016).

Altmann, Peter, and Anna Angelini. "Purity, Taboo and Food in Antiquity: Theoretical and Methodological Issues." In Food Taboos and Biblical Prohibitions: Reassessing Archaeological and Literary Perspectives, ed. Peter Altmann, Anna Angelini, and Abra Spiciarich (Tübingen: Mohr Siebeck, 2020), 9-24.

Angelini, Anna. "The Reception and Idealization of the Torah in the Letter of Aristeas: The Case of the Dietary Laws." Hebrew Bible and Ancient Israel 9 (2020), 435-47.

Azzoni, Annalisa. The Private Lives of Women in Persian Egypt (Winona Lake: Eisenbrauns, 2013).

Azzoni, Annalisa. "Women of Elephantine and Women in the Land of Israel." In In the Shadow of Bezalel: Aramaic, Biblical, and Ancient Near Eastern Studies in Honor of Bezalel Porten, ed. Alejandro F. Botta (Leiden: Brill, 2013), 125-36.

Brubaker, Rogers, and Frederick Cooper. "Beyond 'Identity."' Theory and Society 29 (2000), 1-47.

Clarysse, Willy, Sofie Remijsen, and Mark Depauw. "Observing the Sabbath in the Roman Empire: A Case Study." Scripta Classica Israelica 29 (2010), 51-57.

Cohen, Shaye J.D. The Beginnings of Jewishness: Boundaries, Varieties, Uncertainties (Berkeley: University of California Press, 1999).

Collins, John J. “Artapanus." In The Old Testament Pseudepigrapha, ed. James H. Charlesworth, vol. 2 (New York: Doubleday, 1985), 889-9o3.

Collins, John J. Between Athens and Jerusalem: Jewish Identity in the Hellenistic Diaspora (Grand Rapids: Eerdmans, 2000).

Collins, John J. The Invention of Judaism: Torah and Jewish Identity from Deuteronomy to Paul (Oakland: University of California Press, 2017).

Collins, John J. "The Law in the Late Second Temple Period." The Oxford Handbook of Biblical Law, ed. Pamela Barmash (Oxford: Oxford University Press, 2019), 367-82.

Cowey, James M.S., and Klaus Maresch. Urkunden des Politeuma der Juden von Herakleopolis (144/3-133/2 v. Chr.) (P. Polit. Iud.): Papyri aus den Sammlungen von Heidelberg, Köln, München und Wien (Wiesbaden: Westdeutscher Verlag, 2001).

Czajkowski, Kim, and Stéphanie Wackenier. "Legal Strategies of Judaeans in Herakleopolis, Middle Egypt, according to the Archives of the Politeuma." Hebrew Bible and Ancient Israel 9 (2020), 415-34. 
Dorival, Gilles. "New Light about the Origin of the Septuagint?" In Die Septuaginta-Texte,

Theologien, Einflüsse: 2. Internationale Fachtagung Veranstaltet von Septuaginta Deutsch (LXX.D), Wuppertal 23.-27.7.2008, ed. Wolfgang Kraus and Martin Karrer (Tübingen: Mohr Siebeck, 2010), 36-47.

Fallon, F. “Theodotus.” In The Old TestamentPseudepigrapha, ed.James H. Charlesworth, vol. 2 (New York: Doubleday, 1985), 785-83.

Frei, Peter. "Persian Imperial Authorization: A Summary." In Persia and Torah: The Theory of Imperial Authorization of the Pentateuch, ed. and trans. James W. Watts (Atlanta: Society of Biblical Literature, 2001), 5-40.

Frei, Peter, and Klaus Koch. Reichsidee und Reichsorganisation im Perserreich, 2nd ed. (Fribourg: Editions Universitaires; Göttingen: Vandenhoeck \& Ruprecht, 1996).

Gifford, Edwin H. Eusebii Pamphili Evangelicae Praeparationis libri XV (Oxford: Oxford University Press; New York: Frowde, 1903).

Granerød, Gard. Dimensions of Yahwism in the Persian Period: Studies in the Religion and Society of the Judaean Community at Elephantine (Berlin: De Gruyter, 2016).

Gruen, Erich S. Diaspora: Jews amidst Greeks and Romans (Cambridge: Harvard University Press, 2002).

Grund, Alexandra. Die Entstehung des Sabbats: seine Bedeutung für Israels Zeitkonzept und Erinnerungskultur (Tübingen: Mohr Siebeck, 2011).

Hacham, Noah. "The 'Letter of Aristeas': A New Exodus Story?" Journal for the Study of Judaism 36 (2005), 1-20.

Hart, Herbert L.A. The Concept of Law (New York: Oxford University Press, 1961).

Honigman, Sylvie. "The Birth of a Diaspora: The Emergence of a Jewish Self-Definition in Ptolemaic Egypt in the Light of Onomastics." In Diasporas in Antiquity, ed. Shaye J.D. Cohen and Ernest S. Frerichs (Atlanta: Scholars Press, 1993), 93-128.

Honigman, Sylvie. The Septuagint and Homeric Scholarship in Alexandria: A Study in the Narrative of the "Letter of Aristeas" (London: Routledge, 2003).

Honigman, Sylvie. "Politeumata' and Ethnicity in Ptolemaic and Roman Egypt." Ancient Society 33 (2003), 61-102.

Honigman, Sylvie. "Jewish Communities of Hellenistic Egypt: Diverging Responses to a Varying Socio-Cultural Environment." In Jewish Identities in Antiquity: Studies in Memory of Menahem Stern, ed. Lee I. Levine and Daniel R. Schwartz (Tübingen: Mohr Siebeck, 2009), 117-35.

Honigman, Sylvie. "Jews as the Best of All Greeks': Cultural Competition in the Literary Works of Alexandrian Judaeans of the Hellenistic Period." In Shifting Social Imaginaries in the Hellenistic Period, ed. Eftychia Stavrianopoulou (Leiden: Brill, 2013), 207-32.

Honigman, Sylvie. "The Ptolemaic and Roman Definitions of Social Categories and the Evolution of Judean Communal Identity in Egypt." In Jewish and Christian Communal Identities in the Roman World, ed. Yair Furstenberg (Leiden: Brill, 2016), 23-74. 
Ilan, Tal. "On a Newly Published Divorce Bill from the Judaean Desert." Harvard Theological Review 89 (1996), 195-202.

Joosten, Jan. "Language as Symptom: Linguistic Clues to the Social Background of the Seventy." In Collected Studies on the Septuagint: From Language to Interpretation and Beyond (Tübingen: Mohr Siebeck, 2012), 185-94.

Knoppers, Gary N., and Bernard M. Levinson, eds. The Pentateuch as Torah:New Models for Understanding Its Promulgation and Acceptance (Winona Lake: Eisenbrauns, 2007).

Kratz, Reinhard G. Historical and Biblical Israel: The History, Tradition, and Archives of Israel and Judah, trans. Paul Michael Kurtz (Oxford: Oxford University Press, 2015).

Kratz, Reinhard G. "Fossile Überreste des unreformierten Judentums in fernem Lande'?: Das Judentum in den Archiven von Elephantine und Al-Yahudu." Zeitschrift für die alttestamentliche Wissenschaft 132 (2020), 23-39.

Kreuzer, Siegfried. "The Origins and Transmission of the Septuagint." In Introduction to the Septuagint, ed. Siegfried Kreuzer, trans. David A. Brenner and Peter Altmann (Waco: Baylor University Press, 2019), 3-56.

Kugler, Robert. "Dorotheos Petitions for the Return of Philippa (P.Polit.Jud. 7): A Case Study in the Jews and Their Law in Ptolemaic Egypt." In The Proceedings of the 25th International Congress of Papyrology, ed. Traianos Gagos and Adam Hyatt (Ann Arbor: University of Michigan Press, 2010), 387-96.

Kugler, Robert. "Uncovering a New Dimension of Early Judean Interpretation of the Greek Torah: Ptolemaic Law Interpreted by Its Own Rhetoric." In Changes in Scripture: Rewriting and Interpreting Authoritative Traditions in the Second Temple Period, ed. Hanne von Weissenberg, Juha Pakkala, and Marko Marttila (Berlin: De Gruyter, 2011), 165-76.

Kugler, Robert. "Uncovering Echoes of Lxx Legal Norms in Hellenistic Egyptian Documentary Papyri: The Case of the Second-Century Herakleopolite Nome." In XIV Congress of the IOSCS, Helsinki, 2010, ed. Melvin K.H. Peters (Atlanta: Society of Biblical Literature, 2013), 143-53.

Lange, Armin. "Textual Standardization in Egyptian Judaism and in the Letter of Aristeas." In Die Septuaginta-Texte, Theologien, Einflüsse: 2. Internationale Fachtagung veranstaltet von Septuaginta Deutsch (LXX.D), Wuppertal 23.-27.7.2008, ed. Wolfgang Kraus and Martin Karrer (Tübingen: Mohr Siebeck, 2010), 47-71.

Lee, Kyong-Jin. The Authority and Authorization of Torah in the Persian Period (Leuven: Peeters, 2011).

LeFebvre, Michael. Collections, Codes, and Torah: The Re-Characterization of Israel's Written Law (New York: T\&T Clark, 20o6).

Lippert, Sandra L. "Egyptian Law, Saite to Roman Periods." Oxford Handbooks Online, 2016. http://oxfordhandbooks.com/view/10.1093/oxfordhb/9780199935390.oo1 .ooo1/oxfordhb-978o19993539o-e-48. 
Lippert, Sandra L. "La codification des lois en Égypte à l'époque perse." In Writing Laws in Antiquity = L'écriture du droit dans l'antiquité, ed. Dominique Jaillard and Christophe Nihan (Wiesbaden: Harrassowitz, 2017), 78-98.

Manning, Joseph G. "Demotic Law." In A History of Ancient Near Eastern Law, ed. Raymond Westbrook, vol. 2 (Leiden: Brill, 2003), 819-62.

Manning, Joseph G. The Last Pharaohs: Egypt Under the Ptolemies, 305-30 BC (Princeton: Princeton University Press, 2010).

Mason, Steve. "Jews, Judaeans, Judaizing, Judaism: Problems of Categorization in Ancient History." Journal for the Study of Judaism 38 (2007), 457-512.

Mélèze Modrzejewski, Joseph. The Jews of Egypt: From Rameses II to Emperor Hadrian, trans. Robert Cornman (Skokie: Varda, 2001).

Mélèze Modrzejewski, Joseph. "The Septuagint as Nomos: How the Torah Became a 'Civil Law' for the Jews of Egypt." In Critical Studies in Ancient Law, Comparative Law and Legal History: Essays in Honour of Alan Watson, ed. John W. Cairns and Olivia F. Robinson (Oxford: Hart, 2001), 183-99.

Moore, Stewart Alden. Jewish Ethnic Identity and Relations in Hellenistic Egypt: With Walls of Iron? (Leiden: Brill, 2015).

Orlinsky, Harry Meyer. "Septuagint as Holy Writ and the Philosophy of the Translators." Hebrew Union College Annual 46 (1975), 89-114.

Porten, Bezalel. Archives from Elephantine: The Life of an AncientJewish Military Colony (Berkeley: University of California Press, 1968).

Rajak, Tessa. Translation and Survival: The Greek Bible of the Ancient Jewish Diaspora (Oxford: Oxford University Press, 2009).

Robertson, R.G. "Ezekiel the Tragedian." In The Old Testament Pseudepigrapha, ed. James H. Charlesworth, vol. 2 (New York: Doubleday, 1985), 8०3-19.

Sänger, Patrick. "Die Jurisdiktion der jüdischen Gemeinde von Herakleopolis: Normaloder Sonderfall im hellenistischen Ägypten?” In Symposion 2015: Vorträge zur griechischen und hellenistischen Rechtsgeschichte (Coimbra, 1.-4. September 2015), ed. Delfim F. Leão and Gerhard Thür (Vienna: Österreichische Akademie der Wissenschaften, 2016), 215-32.

Sänger, Patrick. Die ptolemäische Organisationsform politeuma: Ein Herrschaftsinstrument zugunsten jüdischer und anderer hellenischer Gemeinschaften (Tübingen: Mohr Siebeck, 2019).

Schenker, Adrian. "Was führte zur Übersetzung der Tora ins Griechische? Dtn 4,2-8 und Platon (Brief VII,326a-b)." In Die Septuaginta - Texte, Theologien, Einflüsse: 2. Internationale Fachtagung veranstaltet von Septuaginta Deutsch (LXX.D), Wuppertal 23-27.7.2008, ed. Wolfgang Kraus and Martin Karrer (Tübingen: Mohr Siebeck, 2010), 23-35. 
Ska, Jean Louis. “Persian Imperial Authorization': Some Question Marks." In Persia and Torah: The Theory of Imperial Authorization of the Pentateuch, ed. James W. Watts (Atlanta: Society of Biblical Literature, 2001), 115-34.

Stearns, Wallace N. Fragments from Graeco-Jewish Writers (Chicago: University of Chicago Press, 1908).

Van der Toorn, Karel. Becoming Diaspora Jews: Behind the Story of Elephantine (New Haven: Yale University Press, 2019).

Vroom, Jonathan. The Authority of Law in the Hebrew Bible and Early Judaism: Tracing the Origins of Legal Obligation from Ezra to Qumran (Leiden: Brill, 2018).

Watts, James W., ed. Persia and Torah: The Theory of Imperial Authorization of the Pentateuch (Atlanta: Society of Biblical Literature, 2001).

Weber, Reinhard. Das Gesetz im hellenistischen Judentum: Studien zum Verständnis und zur Funktion der Thora von Demetrios bis Pseudo-Phokylides (Frankfurt am Main: Lang, 2000).

Wolff, Hans Julius, and Hans-Albert Rupprecht. Das Recht der griechischen Papyri Ägyptens in der Zeit der Ptolemäer und des Prinzipats (Munich: Beck, 1978).

Wright, Benjamin G. Praise Israel for Wisdom and Instruction: Essays on Ben Sira and Wisdom, the Letter of Aristeas and the Septuagint (Leiden: Brill, 2008).

Wright, Benjamin G. The Letter of Aristeas: "Aristeas to Philocrates" or "On the Translation of the Law of the Jews" (Berlin: De Gruyter, 2015). 